\title{
Anti-Fungal Properties of Ficus exasperata, Jathropha curcas and Mangifera indica on Fusarium oxysporium Causing Seed Rot and Seedling Blight in Soybean
}

\author{
Wikiri, J., Nwauzoma, A.B*. \& Nmom, F.W. \\ Department of Plant Science \& Biotechnology, Rivers State University, Nkpolu-Oroworukwo, Port Harcourt, Nigeria.
}

\begin{abstract}
Soybean is affected by a wide range of diseases, many of which are seed-borne. In vitro and in vivo studies were conducted on the control of Fusarium oxysporium the causal pathogen of soybean seed rot using three plant leaf extracts. Laboratory experiments were conducted with aqueous extracts of air dried leaves of Ficus exasperata, Jatropha curcas, and Mangifera indica and a synthetic fungicide Mancozeb. Using the poisoned food technique, various concentrations $(20,40$, and $60 \%)$ of the leaf extracts and Mancozeb $(0.002 \%)$ utilized inhibited the mycelial growth of the pathogens in vitro. Effects of Mancozeb comparative to the plant extracts were determined. Even though all the extracts showed varying degrees of antifungal efficacy, $60 \%$ concentration of $F$. exasperata had the highest level of inhibition $(64.52 \%)$ on the mycelial growth of the pathogen and was significantly different $(P \leq 0.05)$ from Mancozeb $(83.86 \%)$ after 3 days. Extracts of $J$. curcas and $M$. indica showed a lower inhibition level ranging from $54.80 \%$ to $18.56 \%$ and $54 \%$ to $22.59 \%$ respectively, which were significantly lower in comparison to Mancozeb $(\mathbf{P} \leq \mathbf{0 . 0 5})$. Inhibition of fungal growth increased with a corresponding increase in extract concentration and days. The plant leaf extracts effectively inhibited mycelial growth of the pathogen in vitro after 3 days. The efficacy of seed treatments against seedborne $F$. oxysporium were evaluated under greenhouse conditions at 40 and $60 \%$ concentrations. The result indicated that seeds of various soybean varieties (TGX1448, TGX198710F, TGX 1988-5F) treated with $60 \%$ concentration of $F$. exasperata performed better than the others and improved seed germination: $33.33 \%$ in TGX1448 and TGX1987-10F and $26.67 \%$ in TGX 1988-5F. The number of leaves was 4.33, 5.0 and 3.67 in TGX1448, TGX1987-10F, TGX 1988-5F respectively; while stem length was $18.33 \mathrm{~cm}, 18.67 \mathrm{~cm}, 15.00 \mathrm{~cm}$ respectively, in the above order. However, the results were lower and statistically different $(P \leq 0.05)$ from Mancozeb and the uninoculated control. The results obtained in this study confirmed that Jathropha curcas, Ficus exasperata, and Mangifera indica possess potential inhibitory effect on Fusarium oxysporium, one of the causal agents of Soybean seed rot and seedling blight.
\end{abstract}

Keywords:- Soybean, Mancozeb, Seed-borne fungi, In vitro, In vivo.

\section{INTRODUCTION}

Soybean (Glycine max L.) (Merill) is an important cereal legume crop grown for its high quality protein, edible oil, food-derived products and ability to improve soil fertility through biological nitrogen fixation (Ugbabe et. al, 2017). Soybean has a wide range of geographical adaptation, unique chemical composition, nutritional value, functional health benefits, and industrial applications (Masuda and Goldsmith, 2009). The protein content in the seed is approximately $40 \%$, and the oil content is about $20 \%$. In fact, soybean represents the highest protein content and gross output of vegetable oil among the cultivated crops, providing about $60 \%$ of vegetable protein and $30 \%$ of the total vegetable oil production in the world (Medic et al., 2014). The use of soybean has increased in human nutrition and health, edible oil, livestock feed, biofuel, and other industrial and pharmaceutical applications (Chiu et al., 2004; Hammond and Vicini, 1996).

Seed-borne fungal diseases are among the most important factors limiting the production of grain legumes in many countries, resulting in serious economic losses (Shovan et al., 2008). Several pathogenic fungi are reported to be responsible for seed and seedling diseases in soybean. Seeds of soybean are known to harbor several species of seed borne fungi namely, Fusarium oxysporum, Cercospora kikuchi, Alternaria alternata, Aspergillus flavus, Penicillium sp. and Rhizopus stolonifer were found in germinating seeds and seedlings of soybean (Shovan et al., 2008). Fusarium is a cosmopolitan genus of filamentous ascomycete fungi that represents a vast array of agronomically important plant pathogens (Geiser et al., 2013). Fusarium wilts or blights, seed, seedling, stem and root rots are typical diseases that cause economic losses in cash crops, horticultural, ornamental, and forest industries worldwide (Leslie and Summerell, 2006). Recently Fusarium was listed among the top 10 most important plant pathogenic fungi of crops (Dean et al., 2012). On soybeans, Fusarium can cause several diseases such as sudden death syndrome (SDS), Fusarium blight or wilt, root and pod rot caused by several species (Miller and Roy, 1982).

The use of chemicals has aided in the management of seedborne diseases of soybean but numerous problems such as, non-biodegradable substances, high cost, development of resistance in target organism, phytotoxicity, 
hazard to man and environment and not easily available have rendered chemicals either difficult to adopt or farmers have rejected them, for various cultural and religious reasons (Okigbo and Odurukwe, 2009). However, sustainable and eco-friendly management strategies are being employed. Thus, studies on the use of plant extracts as alternatives or complimentary to synthetic chemicals in plant disease management are been given much attention in scientific literature. Plant-based products are generally affordable, readily available, non-phytotoxic and easily biodegradable. Moreso, they are ecofriendly and stand as alternative to chemical fungicides as reported by different scholars (Okigbo and Omodamiro 2006; Okigbo and Nmeka 2005; Akueshi et al., 2002 and Okigbo and Igwe 2007). This study was aimed at evaluating the antifungal attributes of leaf extracts of Ficus exasperata, Jathropha curcas and Mangifera indica against Fusarium oxysporium the causal organism of soybean seed root and seedling blight.

\section{MATERIALS AND METHOD}

\section{Source of materials}

Soybean seeds showing rot symptoms were collected from the University of Port Harcourt greenhouse, Rivers State, Nigeria (4'54'18.7' 'N 6055'21.9' 'E). Mancozeb, a synthetic fungicide was obtained from the Rivers State Agricultural Development Programme (ADP) Port Harcourt, Nigeria.

\section{$>$ Isolation of Fungal Pathogens from Infected Seeds} Infected Soybean seeds were surface sterilized in 5\% Sodium hypochlorite. They were rinsed thrice in sterile distilled water (SDW) (Ritchie, 1991) and kept on a sterile filter paper for about 30 minutes to dry. The seeds were then on to Petri dishes containing sterilized

Potato Dextrose Agar (PDA) and incubated at $28 \pm 2{ }^{\circ} \mathrm{C}$ for 4 days and examined for fungal growth.

\section{Subculturing, Purification, Identification and pathogenicity}

Following growth, subcultures were prepared using inocula from the different fungi in the mixed cultures to obtain a pure culture. This was done by transferring hyphal tips from the colony edge of the mixed cultures on to fresh plates of PDA, using flame sterilized inoculating needle. Thereafter, the plates were incubated at $28 \pm 2{ }^{\circ} \mathrm{C}$ until pure cultures were obtained. The resulting pure cultures were used for the characterization and subsequent identification of the fungal isolates with the aid of identification guides (Barnett and Hunter, 2008). Stock cultures were maintained on agar slants in McCartney bottles and stored at $4^{\mathrm{O}} \mathrm{C}$ in the refrigerator. For the pathogenicity test, a mycelial disk $(5 \mathrm{~mm})$ of $F$. oxysporium obtained using a flame sterilized cork borer from a 6-day old pure culture was cultured for 7 days in a PDA broth containing $1 \mathrm{~g}$ of PDA mixed in $100 \mathrm{ml}$ sterile distilled water. The culture was filtered using No. 1 Whatman filter paper and transferred into $50 \mathrm{ml}$ distilled water containing
$10 \%$ glucose. Healthy seeds of soybean were soaked in $6.1 \times 10^{6}$ spore suspensions of $F$. oxysporium obtained using a haemocytometer slide for 10 minutes. The inoculated seeds were allowed to stay for 24 hours before they were sown in plastic bags each containing $3 \mathrm{~kg}$ sterilized soil at 5 seeds per bag. Observations on seed germination, seed rot and symptoms on plants were made after 14 days. Reisolation was also made from rotted seeds that failed to germinate and infected seedlings to recover the fungus. The physical properties of the isolated organisms were examined thus confirming it to be $F$. oxysporium.

\section{$>$ Preparation of Leaf Extracts}

Fresh leaves of Mangifera indica, Jathropha curcas and Ficus exasperata were collected and dried at room temperature $\left(28 \pm 2^{\circ} \mathrm{C}\right)$ for 14 to 18 days. The dried leaves were ground into fine powder, using a laboratory mortar and pestle. The powders were stored separately in sterile plastic containers at room temperature $\left(28 \pm 2^{\circ} \mathrm{C}\right)$.

Test concentrations (20\%, $40 \%$ and $60 \%)$ were obtained by mixing $(20 \mathrm{~g}, 40 \mathrm{~g}$, and $60 \mathrm{~g})$ each leaf powder in $100 \mathrm{ml}$ of Sterile Distilled Water, stirred vigorously and kept for 24 hours. The extracts were then decanted, filtered through a Whatman blotter and stored in a refrigerator at $8^{\circ} \mathrm{C}$ and used within 48 hours.

$>$ Effect of Plant Leaf Extracts and Mancozeb on the Diametric growth of Fusarium oxysporium

The test organism was (Fusarium oxysporum) (Plate $1)$ used in the study. The concentrations $(20 \%, 40 \%$ and $60 \%$ ) of plant leaf extracts were obtained. Exactly $39 \mathrm{~g}$ of PDA powder was dispensed in $1000 \mathrm{ml}$ or 1liter of sterile distilled water in a conical flask whose mouth was covered with non-absorbent cotton wool and aluminum foil. This was autoclaved at a temperature $121^{\circ} \mathrm{C}$ and pressure of $15 \mathrm{~atm}$ for 15 minutes. Also, $2 \mathrm{ml}$ of the different concentrations of various plant leaf extracts were mixed with $10 \mathrm{ml}$ PDA and dispensed into Petri dish, the medium was uniformly mixed and allowed to cool and solidify. For positive control, $2 \mathrm{ml}$ of $0.002 \%$ of Mancozeb was mixed with 10ml PDA dispensed into Petri dish and allowed to solidify. Two intersecting lines were drawn at the bottom to determine the center of the plate. A disc (5 mm diameter) of a 3 - 4 day old culture of the fungal pathogen was placed at the center of the Ficus exasperata Potato Dextrose Agar (FEPDA), Jathropha curcas Potato Dextrose Agar (JCPDA), Mangifera indica Potato Dextrose Agar (MIPDA) and media containing $0.002 \%$ Mancozeb. The control experiment had no leaf extract treatment. Exactly 11 plates were treated and each treatment replicated thrice. Total sample size was 33 . Inoculated plates were incubated at temperature of $28 \pm 2{ }^{\circ} \mathrm{C}$. The diameter of the radial growth of the fungus was measured daily for three days and used to detect the fungal toxicity levels of the extracts (Nwauzoma et al., 2016). 
$\%$ growth inhibition $=($ DC-DT $) /($ DC $) \times 100 / 1$

Where DC $=$ The farthest radial distance of pathogen in control plate

DT $=$ The farthest radial distance of pathogen colony in extract incorporated plates

\section{In vivo Study}

Seeds of three varieties of soybean - TGX1448, TGX1987-10F and TGX1988-5F were surface sterilized and artificially inoculated with $F$. oxysporium at $10^{6}$ conidia/ml obtained using a haemocytometer. After 24hours, seeds were again treated separately with $40 \%$ concentration of Ficus exasperata, 60\% concentration of Ficus exasperata, 40\% concentration of Jathropha curcas, $60 \%$ concentration of Jathropha curcas, $60 \%$ concentration of Mangifera indica and Mancozeb along with untreated and pathogen treated seeds. The experiments were done in triplicate using the Randomized Complete Block Design (RCBD) in the screen house. There were a total of 8 treatments per variety and the total sample size was 72 . Seeds after treatment with the various plant extracts and Mancozeb were sown in $3 \mathrm{~kg}$ sterilized soils in perforated plastic bags at the rate of five seeds per bag.

Data were collected on germination percentage, stem length (carried out with the aid of a meter rule) and the number of leaves at 35 days after planting (35 DAP) subjected to Analysis of Variance and means were separated using Duncan's Multiple Range Test at $\mathrm{P}<0.05$.

The details of the experiment are as shown below:

T1 Seed treatment with $40 \%$ concentration of Ficus exasperata

T2 Seed treatment with $60 \%$ concentration of Ficus exasperata
T3 Seed treatment with $40 \%$ concentration of Jathropha curcas

T4 Seed treatment with $60 \%$ concentration of Jathropha curcas

T5 Seed treatment with $60 \%$ concentration of Mangifera indica

T6 Seed treatment Mancozeb

T7 inoculated seeds with Pathogen only

T8 Untreated seeds.

\section{RESULTS AND DISCUSSION}

Effect of Plant Leaf Extracts and Mancozeb on the Diametric Growth of Fusarium oxysporium

The result of the effect of plant extracts and Mancozeb on the diametric of pathogen daily for 3 days is presented in Table 1. Result shows that Mancozeb (45.73\%) had the highest percentage inhibition followed by $F$. exasperata at $60 \%$ concentration $(40.60 \%)$. They were not statistically different from each other $(\mathrm{p}<0.05)$. Also, $M$. indica at $60 \%$ concentration had a percentage inhibition of $29.49 \%$ and was statistically different $(\mathrm{p}<0.05)$ from the other plant leaf extracts. $J$. curcas at $20 \%$ and $40 \%$ concentration did not record any percentage inhibition after 24 hours. Ficus exasperata at $60 \%$ concentration $(53.18 \%)$ had the highest percentage inhibition among the plant extracts but was not statistically different $(\mathrm{p}<0.05)$ from $M$. indica at $60 \%$ concentration $(51.80 \%)$ after 2 days. The percentage inhibition of $F$. exasperata at $60 \%$ concentration $(64.52 \%)$ was higher than and statistically different $(\mathrm{p}<0.05)$ from other plant extracts but was lower and statistically different $(\mathrm{p}<0.05)$ from Mancozeb (83.86) after 3 days (Plate 1). F. exasperata at $40 \%$ concentration was higher and statistically different $(\mathrm{p}<0.05)$ from $J$. curcas at $60 \%$ concentration and $M$. indica at $60 \%$ concentration.

\begin{tabular}{|c|c|c|c|}
\hline \multirow[t]{2}{*}{ Treatments } & \multicolumn{3}{|c|}{ Mean Percentage Inhibition (\%) } \\
\hline & Day 1 & Day 2 & Day 3 \\
\hline F. exasperata $20 \%$ & $2.56^{\mathrm{a}}$ & $17.66^{\mathrm{b}}$ & $37.07^{\mathrm{c}}$ \\
\hline F. exasperata $40 \%$ & $16.03^{\mathrm{c}}$ & $45.58^{\mathrm{de}}$ & $59.66^{\mathrm{g}}$ \\
\hline F. exasperata $60 \%$ & $40.60^{\mathrm{e}}$ & $53.18^{\mathrm{f}}$ & $64.52^{\mathrm{h}}$ \\
\hline J. curcas $20 \%$ & $0.00^{\mathrm{a}}$ & $6.32^{\mathrm{a}}$ & $18.56^{\mathrm{b}}$ \\
\hline J. curcas $40 \%$ & $0.00^{\mathrm{a}}$ & $22.75^{\mathrm{b}}$ & $42.72^{\mathrm{d}}$ \\
\hline J. curcas $60 \%$ & $13.46^{\mathrm{bc}}$ & $41.69^{\mathrm{cd}}$ & $54.80^{\mathrm{f}}$ \\
\hline M. indica $20 \%$ & $0.00^{\mathrm{a}}$ & $6.32^{\mathrm{a}}$ & $22.59^{b}$ \\
\hline M. indica $40 \%$ & $8.12^{\mathrm{ab}}$ & $37.94^{\mathrm{c}}$ & $47.56^{\mathrm{e}}$ \\
\hline M. indica $60 \%$ & $29.49^{\mathrm{d}}$ & $51.80^{\mathrm{ef}}$ & $54.00^{f}$ \\
\hline Mancozeb & $45.73^{\mathrm{e}}$ & $74.64^{\mathrm{g}}$ & $83.86^{\mathrm{i}}$ \\
\hline Control & $0.00^{\mathrm{a}}$ & $0.00^{\mathrm{a}}$ & $0.00^{\mathrm{a}}$ \\
\hline
\end{tabular}

Table 1:- Effect of Plant Extracts and Mancozeb on the Diametric Growth of Fusarium oxysporium

Pair of means with similar super scripts are not significantly different, according to DMRT $(\mathrm{p}<0.05)$ 

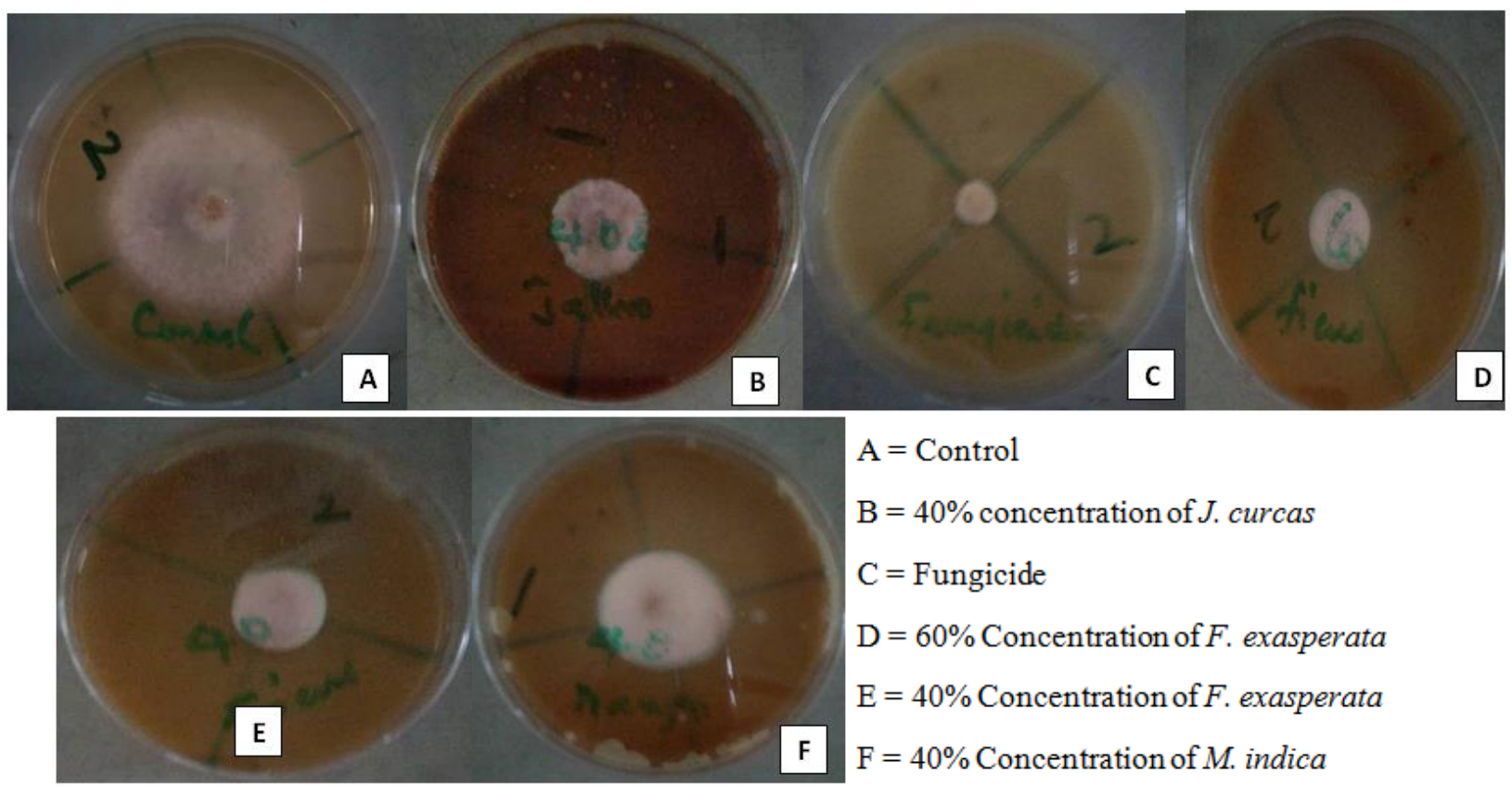

Plate 1:- Effect of Plant Extracts and Mancozeb on the Mycelial Growth of F. oxysporium

\section{Germination Rate}

The result of the effect of treatment methods on percentage germination rate is presented in Table 2 . It shows that TGX1448 in Mancozeb (40\%) had the second highest percentage germination rate behind uninoculated control though they were not statistically different $(\mathrm{p}<0.05)$. $F$. exasperata at $60 \%$ concentration $(33.33 \%)$ performed better that the other plant extracts and was statistically different $(\mathrm{p}<0.05)$ from inoculated control $(13.33 \%)$ but was not statistically different $(\mathrm{p}<0.05)$ from $J$. curcas at $60 \%$ and $40 \%$ concentrations $(26.67 \%$ and $20 \%$ respectively).

Similar result was obtained for TGX1987-10F. Mancozeb (46.67\%) performed better that the plant extracts but was not statistically different $(\mathrm{p}<0.05)$ from $F$. exasperata at $60 \%$ concentration $(33.33 \%)$ and statistically different $(\mathrm{p}<0.05)$ from $J$. curcas at $60 \%$ concentration (20\%) and $M$. indica at $60 \%$ concentration (20\%). Uninoculate control was not statistically different $(\mathrm{p}<0.05)$ from Mancozeb but was statistically different $(\mathrm{p}<0.05)$ from the plant extracts.

Result obtained for TGX1988-5F shows that J. curcas at $60 \%$ concentration, $F$. exasperata at $40 \%$ and $60 \%$ $(26.67 \%)$ had the highest percentage germination rate among the plants extract but was not statistically different $(\mathrm{p}<0.05)$. They were lower and also not statistically different $(\mathrm{p}<0.05)$ from Mancozeb $(46.67 \%)$ but statistically different from uninoculated control $(53.33 \%)$. Plate 1 shows seed rot and seedling blight of soybean caused by $F$. oxysporium.

\begin{tabular}{|c|c|c|c|}
\hline Treatments & TGX1448 & TGX1987-10F & TGX1988-5F \\
\hline F. exasperata $60 \%$ & $33.33^{\mathrm{bcd}}$ & $33.33^{\mathrm{bc}}$ & $26.67^{\mathrm{ab}}$ \\
\hline F. exasperata $40 \%$ & $20^{\mathrm{ab}}$ & $26.67^{\mathrm{ab}}$ & $26.67^{\mathrm{ab}}$ \\
\hline J. curcas $60 \%$ & $26.67^{\mathrm{abc}}$ & $20^{\mathrm{ab}}$ & $13.33^{\mathrm{a}}$ \\
\hline J. curcas $40 \%$ & $20^{\mathrm{ab}}$ & $13.33^{\mathrm{a}}$ & $13.33^{\mathrm{a}}$ \\
\hline M. indica $60 \%$ & $13.33^{\mathrm{a}}$ & $20^{\mathrm{ab}}$ & $46.67^{\mathrm{bc}}$ \\
\hline Mancozeb & $40^{\mathrm{cd}}$ & $46.67^{\mathrm{cd}}$ & $13.33 \mathrm{a}$ \\
\hline Inoculated Control & $13.33^{\mathrm{a}}$ & $13.33^{\mathrm{a}}$ & $53.33^{\mathrm{c}}$ \\
\hline Uninoculated & $46.67^{\mathrm{cd}}$ & $53.33^{\mathrm{d}}$ & \\
\hline
\end{tabular}

N.B. Pair of means with same super script are not significantly different

Table 2:- Effect of Plant Leaf Extracts and Mancozeb on the Percentage Germination Rate

\section{Number of Leaves}

The result of the effect of treatment methods on number of leaves is presented in table 3. Result for TGX1448 shows that Mancozeb (6.00) produced the second highest number of leaves behind Uninoculated control though they were not statistically different $(\mathrm{p}<0.05)$. $F$. exasperata at $60 \%$ concentration (4.33) performed better that the other plant extracts and was statistically different $(\mathrm{p}<0.05)$ from inoculated control (1.33) and $M$. indica at $60 \%$ concentration (1.67).

Similar result was obtained for TGX1987-10F. Mancozeb (6.67) performed better that the plant extracts but was not statistically different $(\mathrm{p}<0.05)$ from $F$. exasperata at $60 \%$ concentration (5.00). All the plant extracts were not statistically different $(\mathrm{p}<0.05)$. 
Result obtained for TGX1988-5F shows that $F$. exasperata at $40 \%$ and $60 \%$ (3.67 both) had the highest number of leaves among the plants extract but were not statistically different $(\mathrm{p}<0.05)$ from the other plant extracts. They were however lower and statistically different from both uninoculated control (7.33) and Mancozeb (7.21).

\begin{tabular}{|c|c|c|c|}
\hline Treatment & TGX1448 & TGX1987-10F & TGX1988-5F \\
\hline F. exasperata $40 \%$ & $2.33^{\mathrm{ab}}$ & $3.33^{\mathrm{ab}}$ & $3.67^{\mathrm{a}}$ \\
\hline F. exasperata $60 \%$ & $4.33^{\mathrm{bc}}$ & $5.00^{\mathrm{bc}}$ & $1.67^{\mathrm{a}}$ \\
\hline J. curcas $40 \%$ & $2.00^{\mathrm{ab}}$ & $1.33^{\mathrm{a}}$ & $3.33^{\mathrm{a}}$ \\
\hline J. curcas $60 \%$ & $3.33^{\mathrm{ab}}$ & $2.33^{\mathrm{ab}}$ & $1.67^{\mathrm{a}}$ \\
\hline M. indica $60 \%$ & $1.67^{\mathrm{a}}$ & $2.67^{\mathrm{ab}}$ & $7.21^{\mathrm{b}}$ \\
\hline Mancozeb & $6.00^{\mathrm{c}}$ & $6.67^{\mathrm{c}}$ & $1.33^{\mathrm{a}}$ \\
\hline Inoculated Control & $1.33^{\mathrm{a}}$ & $1.33^{\mathrm{a}}$ & $7.33^{\mathrm{c}}$ \\
\hline Uninoculated & $6.33^{\mathrm{c}}$ & & \\
\hline
\end{tabular}

N.B. Pair of means with similar super script are not significantly different

Table 3:- Effect of Plant Leaf Extracts and Mancozeb on the Number of Leaves

\section{Stem Length}

The result of the effect of the various treatment methods on the stem length of three varieties of soybean is presented in table 4. Result for TGX1448 shows that uninnoculated control had the highest stem length $(26.00 \mathrm{~cm})$ followed by and not statistically different $(\mathrm{p}<0.05)$ from Mancozeb $(22.00 \mathrm{~cm})$ but statistically different from $F$. exasperata at $60 \%$ concentration $(18.33 \mathrm{~cm})$. Inoculated control had the lowest stem length $(4.33 \mathrm{~cm})$ and was not statistically different $(\mathrm{p}<0.05)$ from $M$. indica at $60 \%(5.00 \mathrm{~cm}), F$. exasperata at $40 \%$ concentration $(10.67 \mathrm{~cm})$ and J. curcas at $40 \%$ concentration $(8.33 \mathrm{~cm})$. It was however statistically different from $J$. curcas at $60 \%(12.33 \mathrm{~cm})$.

The result of the variety TGX1987-10F was similar to TGX1448. The stem length of Uninoculated control $(28.67 \mathrm{~cm})$ was higher than but not statistically different $(\mathrm{p}<0.05)$ from Mancozeb $(25.67 \mathrm{~cm})$. Among the plant extracts, F. exasperata at $60 \%$ concentration $(18.67 \mathrm{~cm})$ had the highest stem length but was not statistically different $(\mathrm{p}<0.05)$ from $F$. exasperata at $40 \%$ concentration $(14.00 \mathrm{~cm})$ and $J$. curcas at $60 \%$ concentration $(11.00 \mathrm{~cm})$. It was however statistically different $(\mathrm{p}<0.05)$ from the inoculated control (5.67), M. indica at $60 \%$ concentration $(9.00 \mathrm{~cm})$ and $J$. curcas at $40 \%$ concentration $(6.67 \mathrm{~cm})$.

Also the result of TGX1988-5F was similar to the other varieties. The stem length of the uninoculated control $(30.33 \mathrm{~cm})$ was higher but not statistically different $(\mathrm{p}<0.05)$ from Mancozeb $(26.33 \mathrm{~cm}) . \quad F$. exasperata at $60 \%$ concentration $(15.00 \mathrm{~cm})$ recorded the highest stem length amount the plant leaf extracts but was not statistically different $(\mathrm{p}<0.05)$ from the inoculated control $(6.33 \mathrm{~cm}), J$. curcas at $40 \%$ and $50 \%$ concentration $(6.33 \mathrm{~cm}$ and $12.67 \mathrm{~cm}$ respectively) and $M$. indica at $60 \%$ concentration $(6.33 \mathrm{~cm})$
Fusarium oxysporium has been reported as the cause of soybean seed rot and seedling blight (Shovan et al., 2008; Gowde et al., 1987; Arya et al., 2004; Dawar et al., 2007; Afzal et al., 2010; Ramesh et al., 2013). The result of this study shows that leaf extracts of Ficus exasperate, Mangifera. Indica and Jathropha curcas significantly inhibited the mycelia growth of $F$. oxysporium. This inhibition of $F$. oxysporium may be attributed to the high levels of phonic substances such as flavonoids, tannins and saponin found in the extracts. This agree with the idea of (Md-mohashine et al., 1997; Oyelana et al., 2011; Chima, 2012; Okey, 2015) Who submitted that antifungal properties of the test plant leaf extracts were effective in controlling Aspergillus flavus, A. niger, Botryodiploidia theobromae, Fusarium oxysporum, F. solani, Penicillium chrysogenum, P. oxalicum and Rhizopus stolonifer. The inhibitory effects of extracts on growth of pathogen varied with concentration of extract. Increase in concentration and days had a corresponding increase in percentage inhibition of growth of the pathogen. This is not unconnected with the increase in the amount of phytochemical constituents. Plant extracts have been reported to improve germination, reduce disease incidence and severity. Haggag et al., (2017) reported that the foliar spray of leaf extracts of Eichhornia crassipes significantly decreased the incidence of net blotch disease of wheat in two field trials compared to the untreated (control) which increased yield.

Conclusively, it is recommended that the use of leaf extracts of Ficus exasperate, Mangifera. Indica and Jathropha curcas should be encouraged as part of an integrated approach for the control of Soybean seed rot and seedling blight. It is also recommended that further investigations should be done on the chemical nature of the active principles of the plants; further investigations can combine the plant extracts for possible synergistic effect. Also, further research involving field trials would be needed to investigate the antifungal effects of these botanicals on Fusarium oxysporium causal organism of Soybean. 


\section{REFERENCES}

[1]. Afzal, R., Mughal, S.M., Munir, M., Sultana, K., Qureshi, R., Arshad, $\mathrm{M}$ and Laghari, M.K. (2010). Mycoflora associated with seeds of different sunflower cultivars and its management. Pakistan Journal of Botany. 42 (1): 435 - 445

[2]. Akueshi, C. O., Kadir, C. O., Akueshi, E. U., Agina, S. E. and Ngurukwem, C. (2002). Antimicrobial potential of Hytissau veoleus Poit (Laminaceae). Nig. J. Botany, 15: 37-41.

[3]. Arya, V. K., Vishunavat, K. and Himanshu N. (2004). Detection, location and transmission of seed borne inoculums of Macrophomina phaseolina in charcoal rot in soybean. J. Mycol. Pl. Pathol., 34 (2): 233-237.

[4]. Barnett, H. H. \& Hunter, B. B. (2008) Illustrated genera of Imperfect fungi. Minnesota. USA: Burgess

[5]. Chima, N. (2012). Antifungal Potencies of Leaf Extracts of Carica papaya On Fungi Implicated in Soft Rot of Yam. Annual Review of Food Science and Technology, 13(2), 202-209

[6]. Chiu, C., Schumacher, L.G., and Suppes, G.J. (2004). Impact of cold flow improvers on soybean biodiesel blend. Biomass Bioenergy, 27:485-491.

[7]. Dawar, S., Farzana, S and Ghaffar, A. 2007. Seed borne fungi associated with chick pea in Pakistan. Pakistan Journal of Botany. 39 (2): 637 - 643.

[8]. Dean, R., Van Kan, J.A., Pretorius, Z.A., HammondKosack, K.E., Di Pietro, A., Spanu, P.D., Rudd, J.J., Dickman, M., Kahmann, R., and Ellis, J. (2012). The top 10 fungal pathogens in molecular plant pathology. Molecular Plant Pathology, 13:414-430.

[9]. Geiser, D.M., Aoki, T., Bacon, C.W., Baker, S.E., Bhattacharyya, M.K., Brandt, M.E., Brown, D.W., Burgess, L.W., Chulze, S., and Coleman, J.J. (2013). One fungus, one name: defining the genus Fusarium in a scientifically robust way that preserves longstanding use. Phytopathology, 103:400-408.

[10]. Haggag, M.W., Abou El Ella, S.M. and Abouziena, H.F. (2017). Phytochemical analysis, antifungal, antimicrobial activities and application of Eichhornia crassipes against some plant pathogens. Planta Daninha, v35:e017159560

[11]. Leslie, J. F., and Summerell, B . A . (2006). The Fusarium laboratory manual. Blackwell Publishing.

[12]. Masuda, T., and Goldsmith, P.D. (2009). World soybean production: area harvested, yield, and longterm projections. International Food and Agribusiness Management Review, 12:143-162

[13]. Md-Mohashine, B., Michiko, N., Seishi, M. \& Tsutomu, S. (1997). Antibacterial effects of the crude Azadirachta indica Neem bark extract on Streptococcus sobrinus. Pediatric Dental Journal, 71, 61-64.

[14]. Medic, J., Atkinson, C., and Hurburgh Jr, C.R. (2014). Current knowledge in soybean composition. Journal of the American Oil Chemists Society, 91:363-384.

[15]. Miller, W.A., and Roy, K.W. (1982). Mycoflora of soybean leaves, pods, and seeds in Mississippi. Canadian Journal of Botany, 60:2716-2723.
[16]. Nwauzoma, A. B., Njoku. C., and Olufolaji, D. B. (2016). Antifungal Attributes of Plant Extracts,

Trichoderma koningii and Dithane M-45 on Sclerotium rolfsii - The Causal Organism of

Cormel Rot of Cocoyam. Nigerian Journal of Mycology, 8, 23 - 24

[17]. Okey, E. N., Duncan, E. J., Sirju-Charran, G. \& Sreenivasan, T. N. (1997). Zoospore germination and growth of Phytophthora palmivora in stem extracts as criteria for assessing cacao resistance. Mycological Research, 101 (6), 683-686.

[18]. Okigbo, R. N, Nmeka, I. A. (2005). Control of yam tuber rot with leaf extracts of Xylopia aethiopia and Zingiber officinale. Afri. J. Biotechnol., 4(8): 804-807.

[19]. Okigbo, R. N. and Igwe, D. I. (2007). The antimicrobial effect of Piper guineense "Uziza" and Phyllantus amarus" "ebe benizo' on Candida albican and Streptococcus faecalis. Acta Microbiologica Immunologica Hungarica, 54(4): 353-366.

[20]. Okigbo, R. N. and Odurukwe, C. N. (2009). Occurrence and control of fungal rot pathogens of yam (Dioscorea rotundata poir) with leaf extracts of Chromolena odorata, Carica papaya and Aspilia Africana. Nig. J. Mycol., 2(1): 154-165.

[21]. Okigbo, R. N. and Omodamiro, O. D. (2006). Antimicrobial effect of leaf extract of pigeon pea (Cajanus cajan (L) Millsp) on some human pathogen. J. Herbs, spices and Med. Plants, 12(2): 117-127.

[22]. Oyelana, O.A., E.U. Durugbo, O.D. Olukanni, E.A. Ayodele, Z.O. Aikulola and A.I. Adewole (2011). Antimicrobial Activity of Ficus Leaf Extracts on Some Fungal and Bacterial Pathogens of Dioscorea rotundata from Southwest Nigeria. Journal of Biological Sciences, 11: 359-366.

[23]. Ramesh, B.V., Hiremath, S.V., Naik, M.K., Amaresh, Y.S., Lokesh, B.K and Vasudevan, S.N. 2013. Study of seed mycoflora of soybean from north eastern Karnataka. Journal of Agricultural Science. 26 (1): 58-62.

[24]. Shovan, L. R., Bhuiyan, M. K. A., Sultana, N., Begum, J. A., \& Pervez, Z. (2008). Prevalence of fungi associated with soybean seeds and pathogenicity tests of the major seed-borne pathogens. International Journal of Sustainable Crop Production, 3:24-33.

[25]. Ugbabe, O.O, Aboulaye, T., Kamara, A. Y., Mbavai, J and Oyinbo, O. (2017). Profitability and Technical efficiency of soybean production in Northern Nigeria. Tropicultura: 3: 35, 203- 214. 